\title{
Case study of the upgrade of an existing office building for low energy consumption and low carbon emissions
}

\author{
Alexandra Charles, Wahid Maref, Claudiane M. Ouellet-Plamondon* \\ École de technologie supérieure, Montreal (ÉTS-Montreal), Université du Québec \\ 1100 Notre-Dame West, Montreal, Quebec, H3C 1K3, Canada \\ *Corresponding author
}

\begin{abstract}
This case study evaluates the best energy efficiency measures of an existing two-story office building from the late 1960s located in Vancouver. Natural gas was used for heating and electricity was used for lighting, cooling and other needs. The building was simulated to match both metered data and bills. The energy model allowed identifying the parameters to reduce the energy consumption and mitigate the impact on $\mathrm{CO}_{2}$-eq emissions. On-site renewable energy supply was simulated. The return on investment (ROI) of the retrofit strategies (building envelope and renewable energy) was calculated to determine the profitability. From the parametric study, the insulation of the wall and roof, the airtightness and window replacement have the most impact on energy saving and allowed reducing $45 \%$ of the total annual energy consumed. These improvements can save more than 70 tons of $\mathrm{CO}_{2}$-eq per year from reducing the natural gas consumption. The return on investment of upgrading the building envelope was 7.7 years in Vancouver. Net zero energy building performance was possible with the addition of photovoltaic solar panel and solar heating to supply the total energy needs of the building, with an ROI of 11.6 years. If we changed the building location to Montreal, the same optimized building envelope reduces the energy consumption by $39 \%$, and the energy saving increases to $56 \%$ when using the electric heating system usually already in place. Overall, building envelope upgrades are solutions to consider to improve energy saving in northern climate.
\end{abstract}

Authors' accepted manuscript

Article published in Energy and Buildings vol. 183 no 15 (2019), p. 151-160

https://doi.org/10.1016/j.enbuild.2018.10.008

(c) 2019. This manuscript version is made available under the CC-BY-NC-ND 4.0 license http://creativecommons.org/licenses/by-nc-nd/4.0/ 


\section{Introduction}

Building upgrades is an excellent opportunity to reduce energy consumption and greenhouse gas emissions [1-4]. In recent years, improving the energy efficiency of a building is a research topic of high interest [5-8]. Most studies focus reduction of the operational energy [9-11]. Building retrofit targets selected building components, such as the heating ventilation and air-conditioning system (HVAC) [9, 12-15]; the energy management systems [2]; the building envelope [1,9, 15] and specific building envelope elements, such as the wall [16-19], the thermal mass [20], the airtightness [21], the insulation $[12,21]$, the lighting of the building [2, 12, 22]. Economic benefits, especially reduction in energy costs and attractive return on energy retrofit investment, are the main driver for energy retrofits decision [2]. Thus the economic analysis is an important part of a building upgrade study.

The energy saving from the office building retrofits varies on a case-by-case basis. In a multi-objective optimization of an office building in Germany, the reduction in operational energy reached a plateau at one-third reduction of operational energy [23]. Retrofit of office buildings in Italy was found to reduce the primary energy by at least 40\% [24]. Retrofit energy saving in four existing class A commercial office building downtown Toronto in Canada reached $0.9 \%$ to $18 \%$ energy saving with LEED and BOMA certification [25]. Energy retrofit measures allowed 29-31\% electricity saving and 19-32\% natural gas saving in low-rise office building in Edmonton, Ottawa and Vancouver [12].

As there are many retrofit options available, energy simulations are required and different tools are available to analyze scenarios. The key to success in a case study is having a confidence in those simulation tools by calibrating or validating them. Several studies focus of the validation of models [26, 27], but surprisingly, there are not many complete cases studied with a validation of an energy model, improvement of the model and with an economic analysis of the improvement. The validation of a model can be done through three processes i) inter-model comparison or ii) empirical and iii) analytical. Model validation is a necessity, but a complex process and it is important to gain confidence in a model that leads you to a parametric study for retrofitting strategies [28], meaning having the possibility to change model input [29]. Detailed model calibration allows a better building prediction [29]. Often the software's user, especially in absence of information on old buildings, make assumptions based on his experience, which leads to high degree of uncertainty [30]. The calibration relies as well on the level of the experiment and measurement accuracy. In order to simplify the calibration process, some researchers [31] are trying multistage calibration, which consists in dividing the entire building into different sub-models and calibrates them separately to obtain an accurate model. The process depends on the objectives of the study, each model is treated differently.

This study investigates the retrofit of an existing office building in Canada from the late 1960s to reduce the annual operational energy, to determine the on-site energy production to reach net zero energy standard and the return of investment (ROI) for a building located in Vancouver. In the current code requirements and policy in Vancouver, Canada, the 
public policies focus on reducing the operational energy from buildings. [32]. Older traditional buildings from the 1950s to 1970s were not insulated, not airtight, which meant high energy consumption [12]. To address these issues, a numerical approach has been adopted to simulate the energy consumption of the office building pre-retrofit conditions, based on both bills and metered data. A sensitivity and parametric study was undertaken to assess and identify the most important parameters affecting the energy performance and the greenhouse gas emissions, as single and combined parameters. Net zero energy is gaining policy attention and the government of British Columbia is aiming to have all new construction net-zero energy ready by 2032 [33]. The profitability of on-site renewable energy measures for net zero energy building was estimated with the return on investment (ROI). In order to see the effect of the location on energy consumption, retrofit measures renewable energy production and ROI, the building was hypothetically moved from Vancouver to Montreal to assess the robustness of the upgrade measures.

\section{Building Energy Model}

\subsection{Case study}

The case study is a two-story office building built in 1969 of a building science consulting firm office located in Vancouver, in British Columbia (Figure 1) [34]. This building was selected because of the quantity and quality of data collected by the consulting firms on his own office, actually their old office and they moved location. Building energy consumption data is often sensitive and not easy to access. This building is a typical two-story office building found in the building typology in Canada [12] and in the United States [15]. The energy simulation was calibrated by both historical energy billed and metered data, for both electricity and natural gas [34]. The exterior wall assembly was made of painted concrete block and gypsum board. The façade surrounding the windows are made of stucco, wood sheathing, fibreglass batts in wood studs, and gypsum board. It is assumed that the structure is made of concrete. Table 1 presents the architectural details and Table 2 the mechanical parameters. Additional data given by the building science consulting firm is given in supplementary electronic materials.

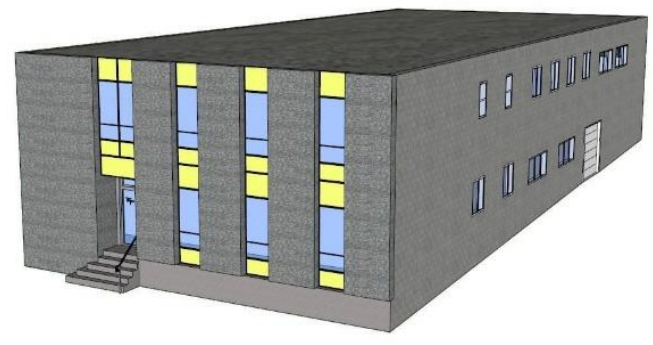

Figure 1: Northwest elevation of the two-storey building from 3D models [34] 
Table 1 : Architectural input of the office building [34]

\begin{tabular}{|c|c|}
\hline Type & Value \\
\hline Total floor area & $922 \mathrm{~m}^{2}$ \\
\hline Total roof area & $463 \mathrm{~m}^{2}$ \\
\hline Gross exposed wall area, North & $90 \mathrm{~m}^{2}$ \\
\hline Gross exposed wall area, South & $90 \mathrm{~m}^{2}$ \\
\hline Gross exposed wall area, East & $92 \mathrm{~m}^{2}$ \\
\hline Gross exposed wall area, West & $204 \mathrm{~m}^{2}$ \\
\hline Window percentage, North & $19.5 \%$ \\
\hline Window percentage, South & $16.3 \%$ \\
\hline Window percentage, East* & $1.5 \%$ \\
\hline Window percentage, West & $9.0 \%$ \\
\hline Infiltration rate (0.29 cfm/ft2) & $1.76 \mathrm{ACH}$ \\
\hline Overall Roof R-Value & $1.97 \mathrm{RSI}$ \\
\hline Overall Wall R-Value & $0.44 \mathrm{RSI}$ \\
\hline Occupancy density & $0.07 \mathrm{people} / \mathrm{m}^{2}$ \\
\hline
\end{tabular}

*Note that the East wall contains a shared portion with the neighboring building and is modelled as adiabatic 
Table 2: Mechanical inputs [34]

\begin{tabular}{|l|c|}
\hline System type & $\begin{array}{c}\text { Direct expansion unitary } \\
\text { system }\end{array}$ \\
\hline Heating & Natural gas \\
\hline Fuel & $80 \%$ \\
\hline Heating efficiency & $20^{\circ} \mathrm{C}$ \\
\hline Setpoint temperature & $17^{\circ} \mathrm{C}$ \\
\hline Setback temperature & 1.0 \\
\hline size factor & \\
\hline Cooling & Electricity \\
\hline Fuel & 3.1 \\
\hline Cooling COP & $22{ }^{\circ} \mathrm{C}$ \\
\hline Setpoint temperature & $26^{\circ} \mathrm{C}$ \\
\hline Setback temperature & 1.0 \\
\hline Size factor & $30^{\circ} \mathrm{C}$ \\
\hline Domestic hot water & $1.4 \mathrm{~L} / \mathrm{m}^{2}$. day \\
\hline Fuel & \\
\hline Mains supply temperature & Natural gas \\
\hline Delivery temperature & $10^{\circ} \mathrm{C}$ \\
\hline Equipment efficiency & $55^{\circ} \mathrm{C}$ \\
\hline Consumption rate & $0.5 / \mathrm{s} . p e r s o n$ \\
\hline Ventilation & $\mathrm{Llslm}{ }^{2}$ \\
\hline Minimum outside air & \\
\hline Mechanical ventilation & \\
\hline temperature & \\
\hline
\end{tabular}




\subsection{Energy simulation}

For building's renovation, the choice of the building and the energy simulation software is an important element in the evaluation and the choice is also oriented toward data availability. There are several tools of energy simulation in North America and more particularly in Canada. Some of the most used software are DOE-2, eQuest, EnergyPlus, EE4, SIMEB, Design Builder, TRNSYS and RETScreen [35, 36]. In this current study, the software used for the energy simulation of this building is SIMEB, software developed by Hydro-Quebec, the electricity provider in Quebec [37]. This software allows estimating the energy consumption of the modelled building, considering the efficiency of energy economy measures, analyzing and comparing with consumption. The pre-retrofit office building operation was previously modelled with Design Builder by the building consulting firm [34]. The energy model for the office building was calibrated to match the metered data and the one-year historical billed energy by varying the unknown mechanical and electrical input parameters. The calibrated model results are very close to the metered data with only $0.5 \%$ annual difference.

The RETScreen software is also used in this study to estimate the additional cost of the improvements brought to the building. It was chosen because it is the commonly used and reliable for energy projects in North America. The software estimates the return on investment (ROI) of such a project and financing options [38]. The ROI calculates the number of years to recover the investment cost. The most important parameters of the simulation are detailed in Table 3. The SHGC is the solar heat gain coefficient, which expresses the ratio between the energy of solar origin that penetrates into the building through the window and the incidental solar energy on the window that becomes a thermal gain and an incidental solar energy on the window.

This building has a poor thermal performance. The exterior walls are having an effective $\mathrm{R}$-value of less than R-3. The roof is a low-sloped built up asphalt roof with minimal insulation. Table 3 below provides a summary of the exterior walls and roof in terms of construction and thermal performance. Overall effective U- and R-values for the wall and roof were calculated using area-weighted $\mathrm{U}$-values from the detailed area calculations. These overall effective walls and roof $\mathrm{U}$-values were calculated to be $2.3 \mathrm{~W} / \mathrm{m} 2 \cdot \mathrm{K}(\mathrm{R}-2.5)$ and $0.51 \mathrm{~W} / \mathrm{m} 2 \cdot \mathrm{K}(\mathrm{R}-11.2)$ respectively. The remaining data necessary to the simulation are in the supplementary electronic materials (Tables S1 and S2). Mechanical and electrical inputs are available in supplementary tables S3 and S4. 
Table 3: Most important data used for the simulation, based on pre-retrofit conditions

\begin{tabular}{|l|c|}
\hline \multicolumn{1}{|c|}{ Modelling data } & Value \\
\hline Insulation of the shell & $\mathrm{RSI}=1.97 \mathrm{~m}^{2} \mathrm{~K} / \mathrm{W}$ \\
\hline Roof & $\mathrm{RSI}=0.88 \mathrm{~m}^{2} \mathrm{~K} / \mathrm{W}$ \\
\hline Walls & No value \\
\hline Floor & $\begin{array}{r}\mathrm{U}=5.91 \mathrm{~W} / \mathrm{m}^{2} \mathrm{~K} \text { and } \\
\mathrm{SHGC}=0.85\end{array}$ \\
\hline Windows & $1.76 \mathrm{ACH}$ \\
\hline Airtightness & \multicolumn{2}{|c|}{ None } \\
\hline Air conditioning & $\begin{array}{l}\text { Saver cycle of the } \\
\text { new air }\end{array}$ \\
\hline
\end{tabular}

The validation of the building model simulated with SIMEB is critical in order to reflect the reality and allows performing parametric study with confidence. This is an inter-model validation process. Furthermore, this stage is necessary so that energy-saving measures are reliable. For that purpose, the data of simulation obtained in this study using SIMEB software has to reach the same or close to energy consumption as those who were obtained by the previous study. Figure 2 presents the total energy consumption (i.e. gas and electricity) obtained with the Design Builder software from January 1, 2006, through May 31 , 2011. Data analysis through that period indicates that approximately $31 \%$ of the building's energy is from gas, and 69\% from electricity.

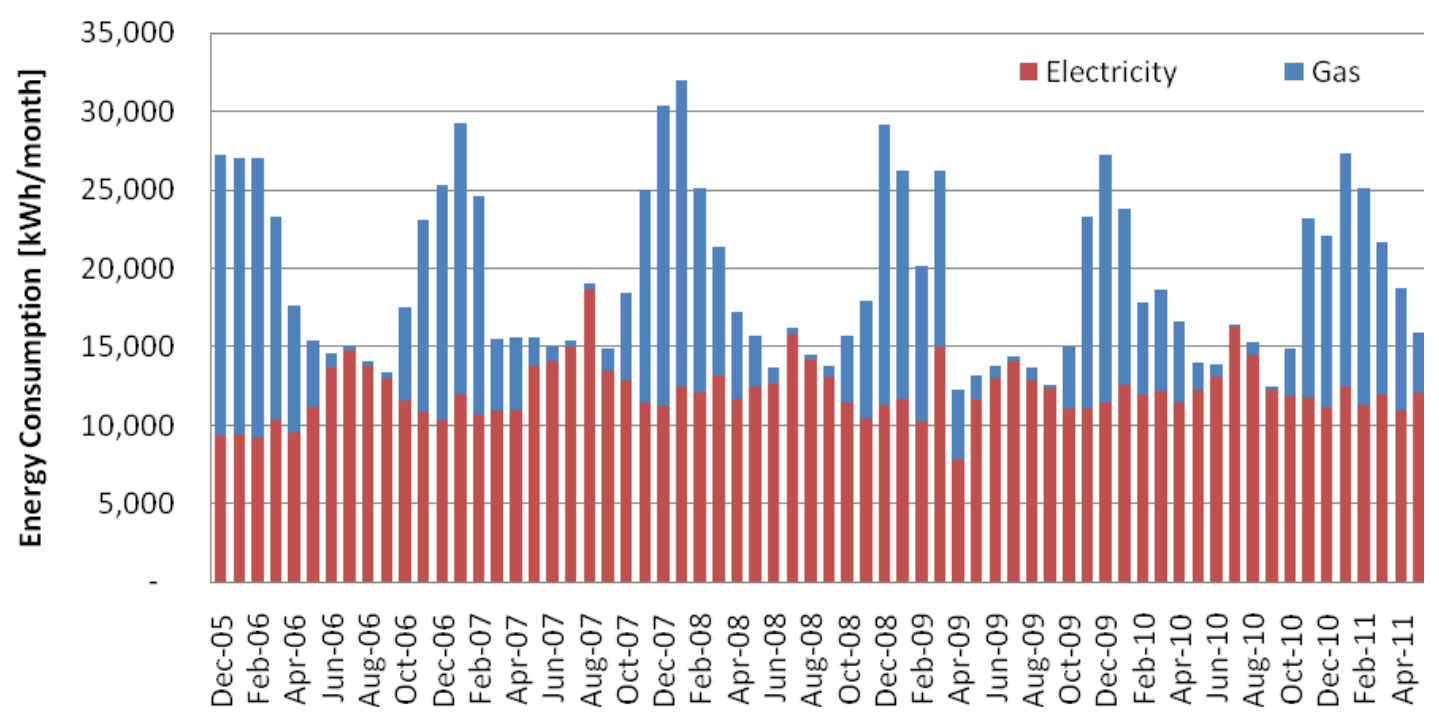

Figure 2 - Total energy consumption from January 1, 2006, through May 31 , 2011 [34].

Figure 3 presents the monthly gas and electricity consumption obtained with Design Builder and those obtained with SIMEB in the pre-retrofit conditions. Seasonal trends are 
observed in both the gas and electrical energy consumption of the building. The gas consumption is only for the heating consumption. The trends of gas are influenced by heat generation and the domestic hot water heater (DHW). The electricity consumption combines the consumption in DHW, electrical loads, lighting and of the systems of ventilation and cooling systems. There is no big difference between the two models SIMEB and Design Builder, based on the total annual average, which is about $252 \mathrm{~W} / \mathrm{m}^{2} / \mathrm{yr}$; the difference on the total is $4 \%$ for the electricity and $3 \%$ for the natural gas. The seasonal differences are due for example because SIMEB consider a minimum insulation and the case study building was less insulated. The SIMEB model was considered validated and acceptable to simulate the energy performance of the retrofitting scenarios of this building.

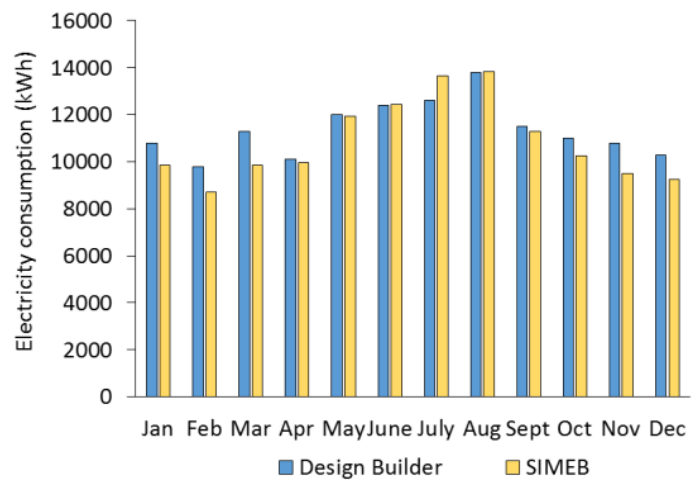

a)

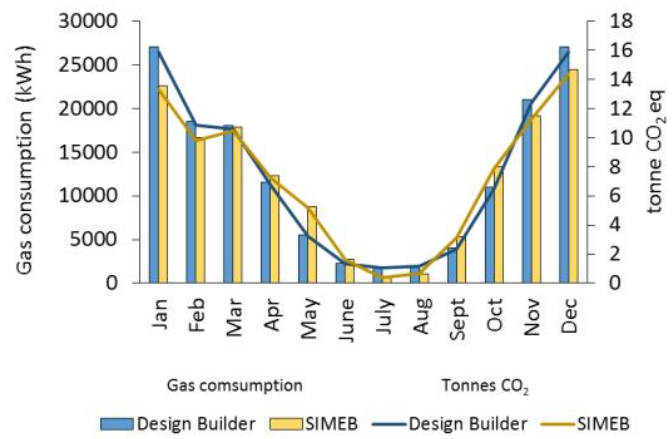

b)

Figure 3: Validation of the pre-retrofit energy consumption with two simulation software: a) electricity consumption, b) gas consumption

\section{Improvement in the building energy performance}

A sensitivity analysis is performed to analyze the impact of the various parameters of the energy simulation on buildings. Once the model is validated, the value of every input was modified to analyze its effects on the building consumption. However, a study of every parameter is not enough, because some simulation parameters are complementary. For example, an improvement of the insulation of walls or another component of the envelope will not allow saving enough energy, if we do not modify the airtightness of the envelope. The sensitivity study shows that the most important inputs to reduce the annual consumption of RDH's building is airtightness of the envelope, wall insulation, roofing insulation and U-Value of Windows. The reduction of multiple parameters is known to be less than the sum of the individual saving [12]. The comparison of the saving of $\mathrm{CO}_{2}$ equivalent was calculated using the generation intensity factor of $587.4 \mathrm{~g} \mathrm{CO}_{2} \mathrm{eq} / \mathrm{kWh}$ for gas use in British Columbia in 2015 [39]. There is no consumption of gas for residential heating purposes in Quebec since 2015 and there is no direct $\mathrm{CO}_{2}$ emission from the hydroelectricity generation. Indirect $\mathrm{CO}_{2}$ emission from energy transport and services were not considered. 


\subsection{Inputs of the sensitivity analysis}

The sensitivity analysis was done for every input available on SIMEB software (Table 4). All the data have a different impact on the annual consumption. The sensitivity analysis shows the most important data for the improvement of the energy efficiency of the office building. The sensitivity study shows that the most important inputs to reduce the annual consumption is the airtightness of the envelope and the insulation of walls, roof and windows. Parameters based on occupants, such as set point temperature, were not the most influential on the overall annual energy consumption.

Table 4: Simulation inputs used for the sensitivity analysis

\begin{tabular}{|l|l|}
\hline Building elements & Inputs \\
\hline Envelope insulation & Walls \\
& Windows \\
& Roof \\
Floor slab
\end{tabular}

\subsection{Single parameter study}

\section{Wall insulation}

The value of the thermal resistance of the insulation of walls is $0.44 \mathrm{~m}^{2} \mathrm{~K} / \mathrm{W}$, which is R2.5. However, the minimal value of the thermal resistance of the insulation of walls in the SIMEB software is $0.88 \mathrm{~m}^{2} \mathrm{~K} / \mathrm{W}(\mathrm{R}-5)$, which was used. Increasing the thermal resistance of the insulation of walls allows to reduce heating consumption, but makes increase the consumption in cooling, as shown in Figure 4. However, savings in heating are more important than the increases of consumption in cooling, especially in cold climate, so the 
total consumption of the building decreases with the increase of the thermal resistance of walls. A wall insulation of $4.88 \mathrm{~m}^{2} \mathrm{~K} / \mathrm{W}$ (R-27) obtained by simulation is an optimum value that allows to reach an annual consumption of $233828 \mathrm{kWh}$ (Figure 4) and deemed complied with the 2015 National Building Code [40]. A decrease of $15 \%$ for the consumption and a saving of 27 tons of $\mathrm{CO}_{2}$ equivalent can be obtained with this insulation.

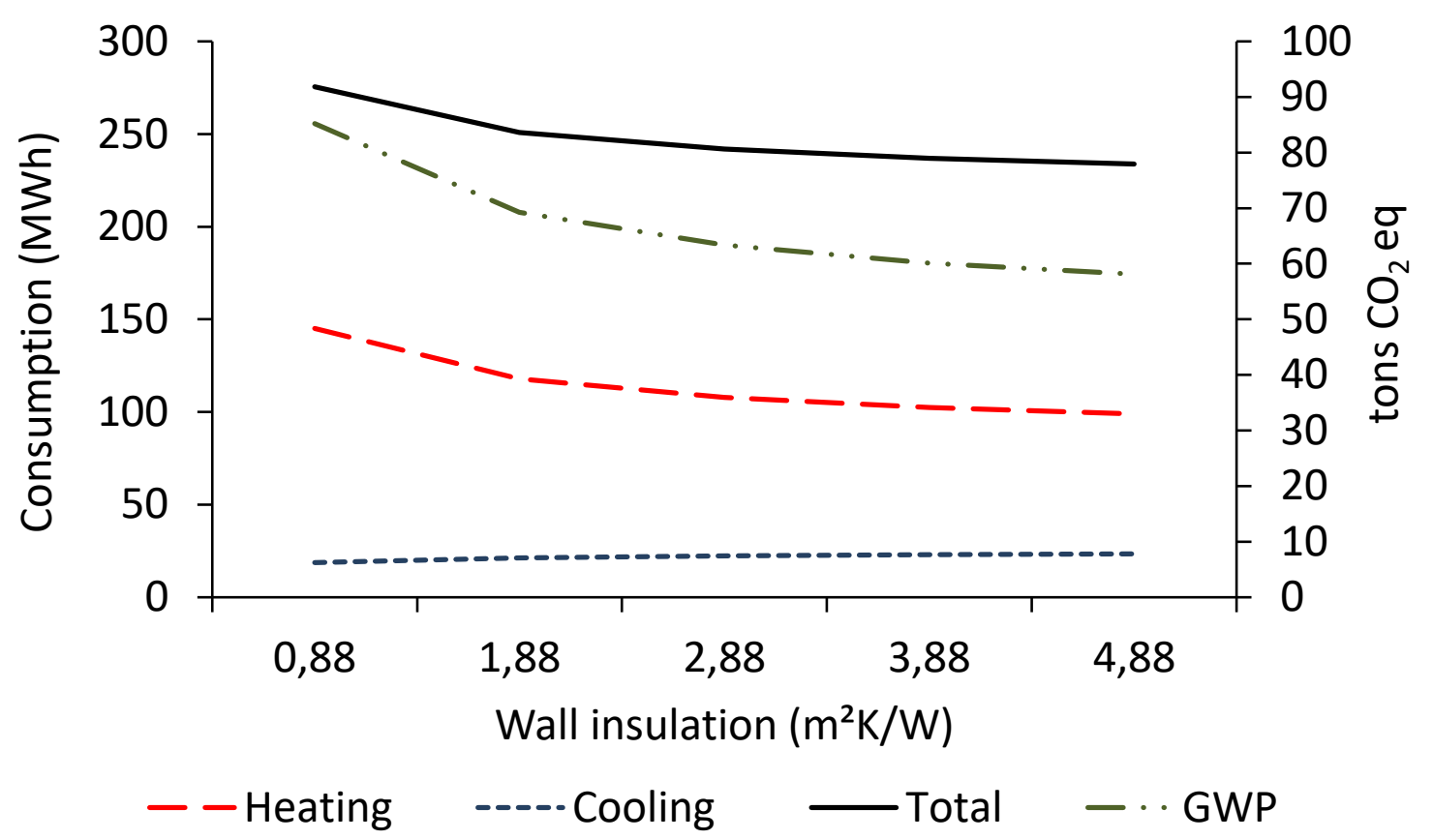

Figure 4: Impact of wall insulation on total consumption ton

\section{Roofing Insulation}

The roof is part of the building envelope of the building. The roof's thermal resistance is RSI of $1.97 \mathrm{~m}^{2} \mathrm{~K} / \mathrm{W}$, which gave us an R-Value of 11 (R11). Increasing the thermal resistance of the roof insulation reduces the consumption for heating but increases the consumption for cooling. A roof insulation of $4.97 \mathrm{~m}^{2} \mathrm{~K} / \mathrm{W}(\mathrm{R}-28)$ is an optimum value obtained by simulation that allows us to reach an annual consumption of $267004 \mathrm{kWh}$ (Figure 5). This represents a decrease of $8 \%$ for the consumption and a saving of 16 tons of $\mathrm{CO}_{2}$ equivalent. 


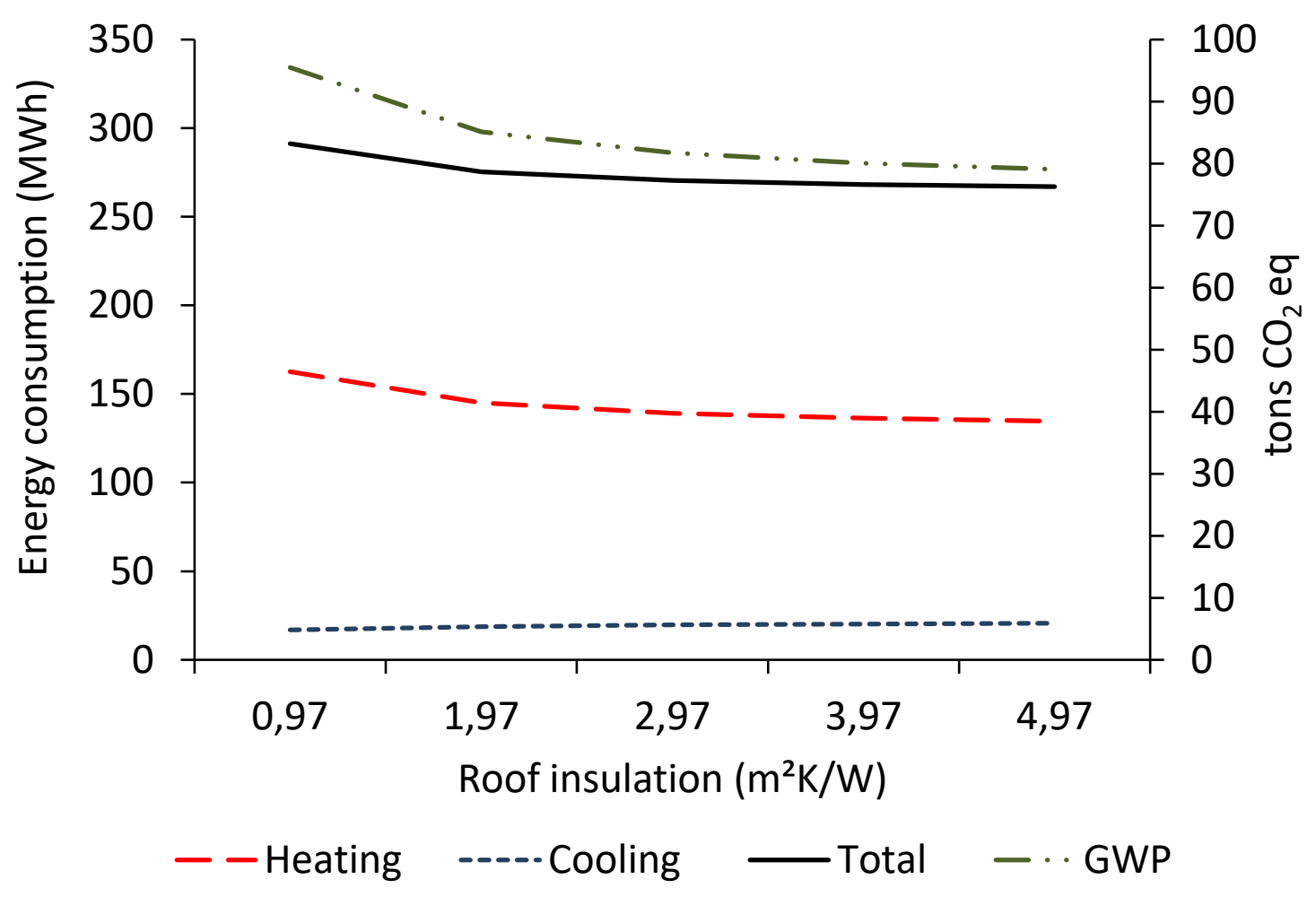

Figure 5: Impact of roof insulation on total energy consumption

\section{Window U-value}

Window energy efficiency is defined by two parameters: global thermal transmission in $\mathrm{W} / \mathrm{m} 2 \mathrm{~K}$ (i.e. U Coefficient or U-Value) and SHGC. Windows settled in the simulated building have a value of global thermal transmission of $5.9 \mathrm{~W} / \mathrm{m} 2 \mathrm{~K}$ and SHGC of 0.85 . The windows consist of clear, $3 \mathrm{~mm}$ single panes in non-thermally broken aluminum window frames. The windows occupy $8.9 \%$ of the exterior wall area and vary in size in shape. SIMEB software proposes several types of windows to model a building. Every type of window corresponds to a global thermal transmission and different SHGC (see supplementary electronic materials Table S5 for more details) [37].

When the global thermal transmission of windows increases, the window allows more heat to pass. When SHGC is increased, the ratio between the energy of solar origin which penetrates into the building through the window and the incidental solar energy on the window is important and so the contribution of solar energy through the window is important. Simulations performed on all types of windows showed that the type allowing the biggest reduction on the total consumption of the building is the high-performance windows double tinted filled with argon and with low emissivity. A total consumption of $269580 \mathrm{kWh}$ represents an annual reduction of $5819 \mathrm{~kW}$, which corresponds to a decrease of $2 \%$ of the total consumption. 


\section{Building envelope airtightness}

The airtightness measures the tightness of the building to outside air. If the rate of airtightness increased, an important quantity of air circulates between the building and the outside, which causes heat losses in winter and thermal heat gain in summer. The unit of the airtightness of the building is the quantity of air change per hour $(\mathrm{ACH})$. The airtightness is essential to ensure that the insulation of the envelope is effective. The initial rate of airtightness measured by the building science-consulting firm was $1.76 \mathrm{ACH}$ and allowed user thermal comfort. American Society of Heating, Refrigerating and AirConditioning (ASHRAE) defines that a tight building corresponds to a rate of airtightness of $0.61 \mathrm{ACH}$, which is also very close to the requirement of $0.6 \mathrm{ACH}$ for a passive house [41]. An average building has generally a rate of airtightness of $1.82 \mathrm{ACH}$; a rate of 3.64 $\mathrm{ACH}$ corresponds to a building with a lot of infiltration of air and thus energy losses. When the value of the rate of airtightness decreases, the annual consumption in heating decreases, whereas the consumption in cooling increases. Savings in heating allow to reduce the total consumption of the building to $245772 \mathrm{kWh}$ (Figure 6). This change impacts a lot the total consumption, which represents the reduction of $11 \%$ in total energy consumption and 19.6 tons of $\mathrm{CO}_{2}$ eq. Even if the energy simulation shows that the value of 0.61 reduce annual consumption, this value is actually hard to achieve. Thus it is not necessary to simulate lower values of $\mathrm{ACH}$.

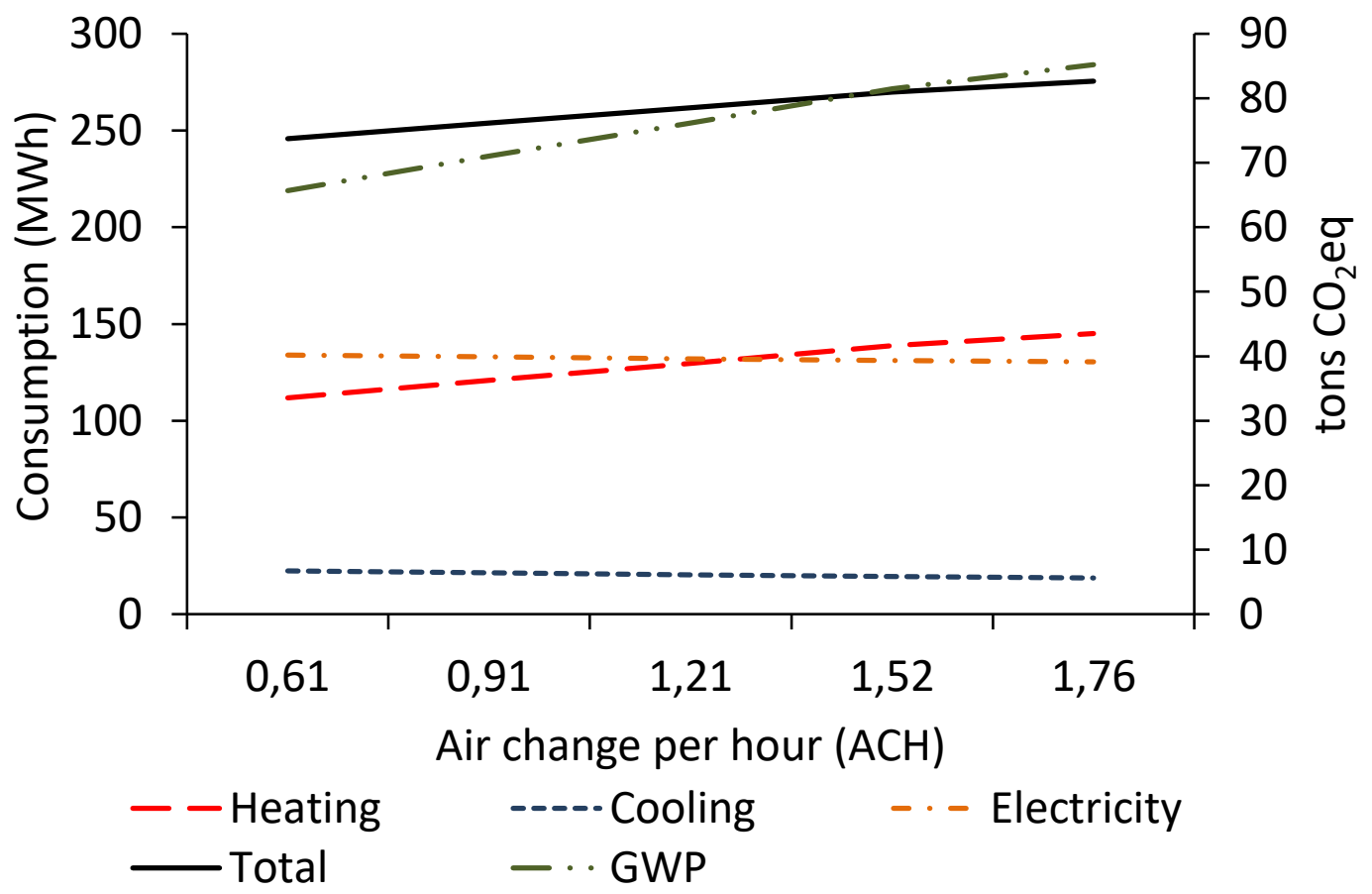

Figure 6: Impact of airtightness on annual energy consumption 


\section{Boiler efficiency}

Boiler efficiency used for the numerical modelling is $80 \%$ with Design Builder. Increase the boiler efficiency allows decreasing the heating consumption. This has no influence on the other consumption. We can increase the efficiency by choosing a certified boiler ENERGY STAR. The efficiency of 95\% allows to reach a total consumption of 252794 $\mathrm{kWh}$, whereas the efficiency of 70\% causes the consumption of $296041 \mathrm{kWh}$ (Figure 7).

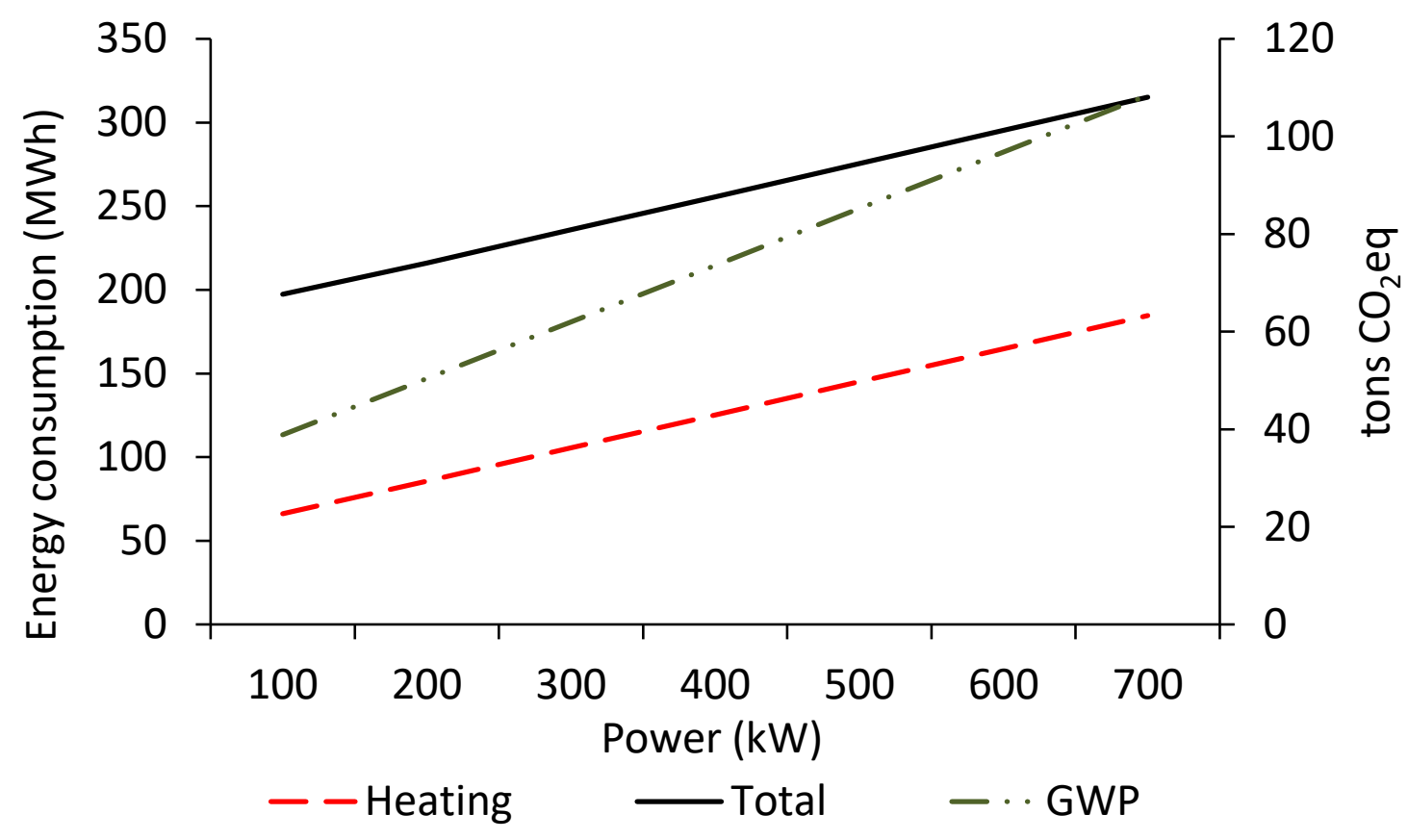

Figure 7: Impact of boiler efficiency on annual building energy consumption

\section{Air conditioning: saving cycle of the new air}

The regulation of the saving cycle is used to reduce mechanical air conditioning. A regulation according to the temperature means that the outside air is used as long as the outside temperature is lower than the recovery temperature. A regulation according to the enthalpy means that the outside air is used as long as the enthalpy of the outside air is lower than the enthalpy of the air of recovery. The saving cycle of the new air according to the temperature of outside air causes an increase of the total annual energy consumption (with an annual consumption of $280225 \mathrm{kWh}$ instead of $275501 \mathrm{kWh}$ ). Whereas the saving cycle of the new air working with the enthalpy of the outside air allows to reduce the total annual consumption of the building (with an annual consumption of $267021 \mathrm{kWh}$ instead of $275501 \mathrm{kWh}$ ). The regulation of free cooling used to reduce the heat load on the mechanical system is carried out by enthalpy measurements. Indeed, the outside air is used for free cooling as long as its enthalpy is lower than that of the indoor air. 


\section{$\underline{3.3 \text { Multiple parameter study }}$}

\section{Roof insulation and airtightness of the building envelope}

Energy consumption was simulated for every value of roof insulation and airtightness of the envelope. If we increase the R-value for roof insulation and decrease the value of airtightness, annual heating consumption decreases whereas annual cooling consumption increases. The criterion to select the building upgrade is to choose the simulation data which allows the biggest total energy saving. A roof insulation of $4.97 \mathrm{~m}^{2} \mathrm{~K} / \mathrm{W}(\mathrm{R}-28)$ and the airtightness of $0.61 \mathrm{ACH}$ (or $0.91 \mathrm{ACH}$ ) reached the minimal annual consumption which is $239032 \mathrm{kWh}$.

\section{Wall insulation and airtightness of the building envelope}

The same method is applied to find the values of wall insulation and airtightness of the envelope, which allow the biggest energy savings. A wall insulation of $4.88 \mathrm{~m}^{2} \mathrm{~K} / \mathrm{W}$ (R27) and the airtightness of $0.61 \mathrm{ACH}$ allows to reach the minimal annual consumption which is $189998 \mathrm{kWh}$. This reduction can save the production of 50 tons of $\mathrm{CO}_{2}$ equivalent gas, which is not negligible gain for $\mathrm{CO}_{2}$ mitigation.

\section{Window insulation and airtightness of the building envelope}

A window insulation of $2.16 \mathrm{~W} / \mathrm{m}^{2} \mathrm{~K}$ with a SHGC value of 0.3 (effective double tinted with argon low E) and the airtightness of $0.61 \mathrm{ACH}$ allows to reach the minimum annual consumption which is $239193 \mathrm{kWh}$. A study of different types of windows on the facades of the building according to their orientation could achieve more energy savings due to an effective insulation in the north and in the east and windows, which allow an important solar heat gain to the south and on the west. The solar heat gain from the windows must not increase the air conditioning consumption. To limit this increase of consumption, it is possible to install flaps or sun visors on the windows of the building.

\section{Global energy savings}

The sensitivity test shows the most important choices to allow a reduction of energy consumption of the building are:

- Improvement of the airtightness of the envelope,

- Improvement of the building insulation,

- Energy efficient equipment,

- A saving cycle of the new air.

The results of the building simulated with SIMEB with the combined parameters allow calculating the total energy savings on the building's annual consumption, based on the basic building and optimized building (Table 4). The basic one is the building simulated with original data and the optimized one is the building simulated with four energy efficiency measures: insulation of the roof and wall, the improvement of windows and the airtightness of the envelope. Building retrofits of the building envelope has more impact in northern climate [1], while it is not the most common retrofit chosen in southern cities in United States [2]. The electricity consumption is the total of the electrical need (lighting, 
etc.) and the cooling of the building. The optimized building requires higher electricity consumption than the basic, this is due total improvement of the envelope, which increases the cooling needs. The cooling of the basic building is only $18720 \mathrm{kWh}$, while the optimized building is about $23110 \mathrm{kWh}$. The optimized building requires a lower gas consumption than the basic one, because the improvement of the envelope decreases the heating needs (Table 5). The heating savings are important in this study. The total consumption of the optimized building is $45 \%$ lower than the basic one, which is comparable to the results of a classical university office building [6]. These changes can save a total of 75 tons of equivalent $\mathrm{CO}_{2}$ gas by reducing only the heat consumption. To compare with another study, the electricity energy saving of a two-story building reached $20 \%$ by applying heat recovery, daylighting, lighting load reduction, boiler efficiency economizer and preheat upgrades, in Edmonton, Ottawa and Vancouver. The natural gas saving of these three cities were $30 \%, 32 \%$ and $19 \%$ respectively [12]. Upgrading the building envelope had more impact on the energy saving.

Table 5: Primary energy savings

\begin{tabular}{|l|l|l|l|}
\hline $\begin{array}{l}\text { Type of } \\
\text { energy } \\
\text { consumption }\end{array}$ & $\begin{array}{l}\text { Basic } \\
\text { building } \\
(\mathrm{kWh})\end{array}$ & $\begin{array}{l}\text { Optimized } \\
\text { building } \\
(\mathrm{kWh})\end{array}$ & $\begin{array}{l}\text { Energy } \\
\text { savings }\end{array}$ \\
\hline Gas heating & 144967 & 17247 & $88 \%$ \\
\hline Electricity & 130449 & 133989 & $2.70 \%$ gain \\
\hline Total & 275416 & 151236 & $45 \%$ \\
\hline
\end{tabular}

RETScreen calculated the additional cost and saving for the improvements, from an initial to an upgrade value (Table 6). The insulation of the walls and roof were panels, as proposed for flat roofs. The new windows were effective double tinted with argon low emissivity. These results show that $83 \%$ of this saving was due to the increase of the insulation of the wall and to the very good airtightness of the building. This represents only $48 \%$ of the total price of the retrofit cost. Improving the windows and the roof efficiency cost more for a limited result, while the airtightness measures offers the best energy saving/additional cost ratio. 
Table 6: Detail energy savings of the combined envelope retrofit

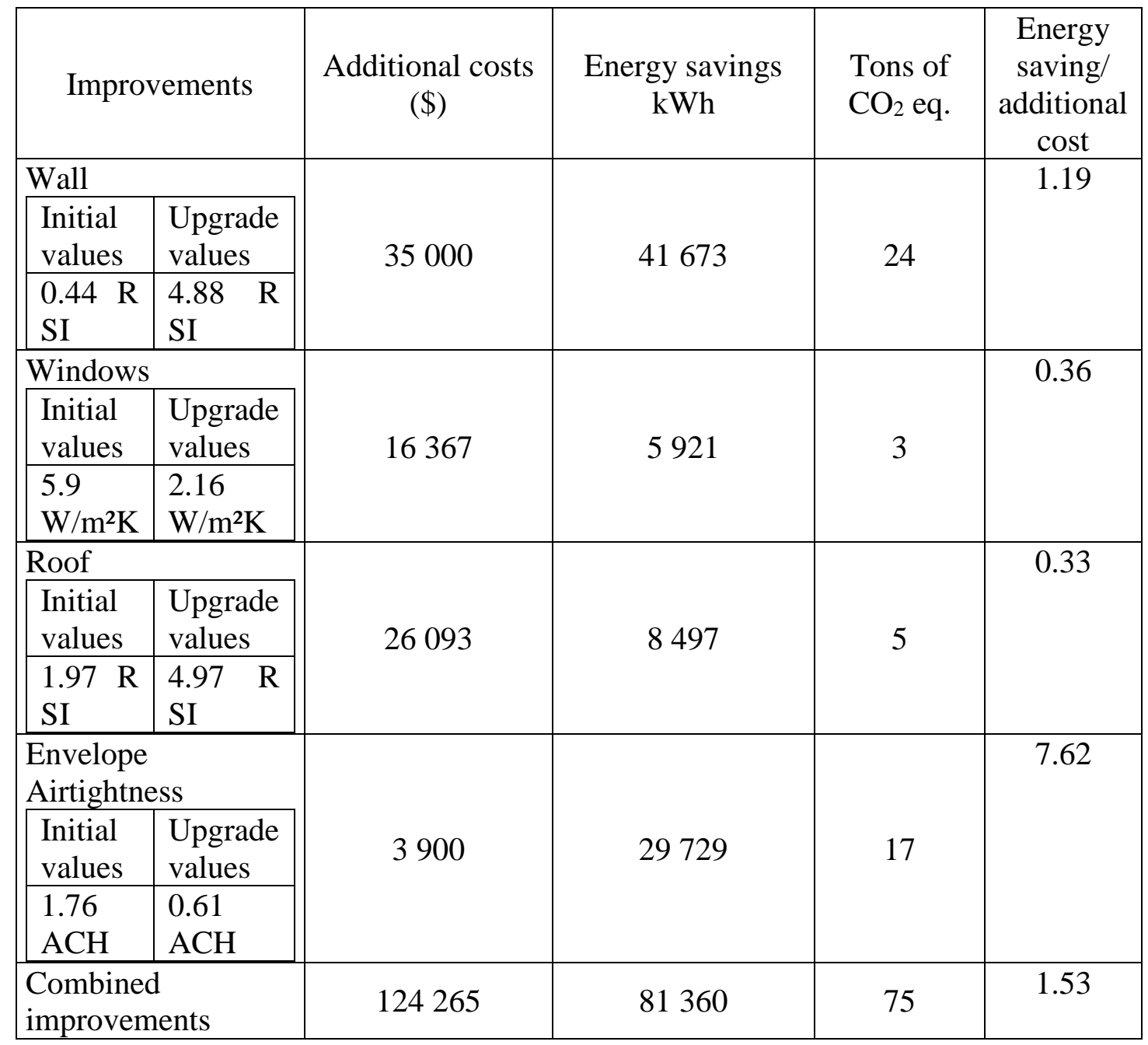

\subsection{Renewable energy and net zero building}

A net zero building produces as much clean energy as it consumes [42], which is easier once the energy consumption is reduced by energy efficiency measures. The addition of on-site renewable energy measured was modelled with RETScreen [38]. The capacity of the solar heating system is $9.1 \mathrm{~kW}$ and the installed surface is $13 \mathrm{~m}^{2}$. The incoming air is sucked in dimples with a great turbulence for maximum heat transfer. For the gas consumption, a solar heating system of the air is a good renewable solution. A solar thermal collector collects heat by absorbing sunlight. The improvement of the envelope and the airtightness of the building allowed a strong fall in demand in heating and what allows filling the remaining needs easily. However, these improvements also caused an increase of the electric consumption because of a bigger need for cooling, supplied by the installation of photovoltaic panels. The table 7 presents the annual consumption and the appropriate sources of renewable power production. The supplied energy was calculated using RETScreen software and the Vancouver solar radiation data. Electricity production 
by the 226 photovoltaic panels with a life cycle efficiency of $16 \%$ represents a surface of $433 \mathrm{~m}^{2}$ (the roof surface is $497 \mathrm{~m}^{2}$ ). The solar collector replaces gas consumption and has a surface of $13 \mathrm{~m}^{2}$. When the renovation of the building is done, it is important to assure a follow-up of the energy performances of the building.

Table 7: Supplied energy for the building

\begin{tabular}{|l|l|l|l|l|}
\hline $\begin{array}{l}\text { Type of } \\
\text { energy } \\
\text { consumption }\end{array}$ & $\begin{array}{l}\text { Annual } \\
\text { consumption } \\
(\mathrm{kWh})\end{array}$ & $\begin{array}{l}\text { Renewable } \\
\text { power } \\
\text { production }\end{array}$ & $\begin{array}{l}\text { Supplied } \\
\text { energy } \\
(\mathrm{kWh})\end{array}$ & $\begin{array}{l}\text { Decrease } \\
\text { of tones } \\
\mathrm{CO}_{2} \text { eq. }\end{array}$ \\
\hline Gas & 17247 & $\begin{array}{l}\text { Solar heating } \\
\text { of the air }\end{array}$ & 17472 & 10.1 \\
\hline $\begin{array}{l}\text { Electricity } \\
\text { consumption }\end{array}$ & 133989 & $\begin{array}{l}\text { Photovoltaic } \\
\text { panels }\end{array}$ & 134315 & NA \\
\hline
\end{tabular}

\subsection{Annual saving and return on investment (ROI)}

Reducing energy needs allows a reduction of operating costs, but there are additional costs for the installation of measures of efficiency energy proposed. Additional costs, the return on investment and savings due to the renovation of the envelope and to the installation of renewable sources of energy were estimated with RETScreen software (Table 8). To measure the profitability of such a project, the return on capital is better than the simple return, because the first one indicates the number of years which it is necessary to get back amounts invested in the project by the investor due to the flows generated. The return on the invested capital takes into account the flows of money of the project from the beginning, but also the financial lever (function of the level of debt), that makes it a better financial indicator of the project than the simple return. With no debt, the ROI is 7.5 years for the retrofit of the building envelope and 11.6 years for the retrofit with the renewable energy production, in Vancouver (Table 9). 
Table 8: Annual savings due to the energy performance

\begin{tabular}{|l|c|c|}
\hline $\begin{array}{l}\text { Measures of } \\
\text { efficiency energy }\end{array}$ & $\begin{array}{l}\text { Additional } \\
\text { costs (\$) }\end{array}$ & Annual savings (\$) \\
\hline $\begin{array}{l}\text { Envelope retrofits } \\
\text { (wall, roof, windows } \\
\text { and airtightness) }\end{array}$ & 81360 & 9452 \\
\hline $\begin{array}{l}\text { Photovoltaic panels } \\
(226 \text { for a surface of } \\
\left.433 \mathrm{~m}^{2}\right)\end{array}$ & 234112 & 12594 \\
\hline $\begin{array}{l}\text { Solar heating of the } \\
\text { air (for a surface of } \\
13 \mathrm{~m}^{2} \text { ) }\end{array}$ & 7280 & 1726 \\
\hline
\end{tabular}

Several data influence the return on own capital: inflation rate, life cycle of the project, debt ratio, interest rate on the debt, duration of the loan, capital costs, possible subsidies and the annual savings [38]. The debt ratio is the most influential value on the return on investment. The lower is the ratio, the lower is the debt, the more the project will be profitable quickly. The returns on investment take into account the duration of the project of 25 years (approximately the life expectancy of a solar panel) and the duration of a loan of 10 years. The return on capital for a $50 \%$ debt ratio (an interest rate of 7\%) is of 13.7 years while considering the renewable energy production and 7.9 years when considering only the building envelope. Other values for the debt ratio are presented in the table 9.

Table 9: Return on investment of the office upgrade scenario in Vancouver (in years)

\begin{tabular}{|l|l|l|l|l|}
\hline Debt ratio & \multicolumn{3}{|l|}{ Return on investment } \\
\hline & \multicolumn{2}{|l|}{ Building envelope } & $\begin{array}{l}\text { Building envelope and renewable } \\
\text { energy }\end{array}$ \\
\hline $0 \%$ & 7.5 years & 11.6 years \\
\hline & Interest rate 2\% & Interest rate 7\% & $\begin{array}{l}\text { Interest rate } \\
2 \%\end{array}$ & Interest rate 7\% \\
\hline $10 \%$ & 7.7 & 7.9 & 11.7 & 12.0 \\
\hline $50 \%$ & 7.1 & 8.7 & 12.2 & 13.7 \\
\hline $90 \%$ & 4.3 & 10.5 & 12.6 & 15.4 \\
\hline
\end{tabular}

\subsection{The application of the study to Montreal, Quebec}

The impact of the building location on consumption, upgrade measures, and return on investment was also performed by moving the building from Vancouver to Montreal, in simulations. The numerical modelling was performed by changing the weather input files in SIMEB and RETScreen from Vancouver to Montreal, to evaluate the relevance of the choices of the improvement of the building. For an office building in Montreal with natural gas, the total consumption is $28 \%$ higher than in Vancouver, due to a $50 \%$ increase in the 
heating consumption in a colder winter climate (Table 10). In Vancouver, electricity costs $0.094 \$ / \mathrm{kWh}$ and gas costs $0.074 \$ / \mathrm{kWh}$, whereas for Montreal electricity costs $0.08 \$ / \mathrm{kWh}$ and gas costs $0.033 \$ / \mathrm{kWh}$, at the commercial rate. Even though the consumption is $28 \%$ higher in Montreal, the energy bill is $21 \%$ lower because of the lower energy price for the basic building (Table 11). If we consider the same energy efficiency measures applied on the building envelope in Vancouver then, the energy needs are reduced by $39 \%$ in Montreal, as compared to $45 \%$ in Vancouver.

Table 10: Consumptions for Vancouver and Montreal.

\begin{tabular}{|l|c|c|c|c|c|c|}
\hline & \multicolumn{3}{|l|}{ Basic building } & \multicolumn{2}{l|}{ Optimized building envelope } \\
\hline $\begin{array}{l}\text { Energy } \\
\text { Consumption }\end{array}$ & Vancouver & Montreal & $\begin{array}{l}\text { Montreal } \\
\text { (all } \\
\text { electric) }\end{array}$ & Vancouver & Montréal & $\begin{array}{l}\text { Montréal } \\
\text { (all } \\
\text { electric) }\end{array}$ \\
\hline $\begin{array}{l}\text { Gas } \\
(\mathrm{kWh})\end{array}$ & 144967 & 216084 & 0 & 17247 & 71698 & 0 \\
\hline $\begin{array}{l}\text { Electricity } \\
(\mathrm{kWh})\end{array}$ & 130449 & 135866 & 239610 & 133989 & 140255 & 154124 \\
\hline $\begin{array}{l}\text { Total } \\
(\mathrm{kWh})\end{array}$ & 275416 & 351950 & 239610 & 151236 & 211953 & 154124 \\
\hline
\end{tabular}

Table 11: Energy costs for Vancouver and Montreal

\begin{tabular}{|l|l|l|l|l|l|}
\hline & \multicolumn{2}{|l|}{ Basic building } & \multicolumn{2}{l|}{ Optimized building envelope } \\
\hline Energy bills & Vancouver & Montréal & Vancouver & Montréal & $\begin{array}{l}\text { Montréal } \\
\text { all } \\
\text { electric) }\end{array}$ \\
\hline Gas bills (\$) & 10728 & 7130 & 1276 & 2366 & \\
\hline Electricity bills (\$) & 12262 & 10870 & 12595 & 11220 & 12330 \\
\hline Total bills (\$) & 22991 & 18000 & 13871 & 13586 & 12330 \\
\hline
\end{tabular}

In Montreal, most buildings are already heated by electricity, buildings are connected on the grid supplied with hydroelectricity. Thus the electric building in Montreal was modeled with SIMEB by using an electric boiler, which is an electric serpentine with the efficiency of $100 \%$, meaning a coefficient of performance of $100 \%$ [43]. For the capacity of the serpentine, an automatic sizing was chosen to supply the total heating needs of the building. Even in the colder climate with no building upgrade, the energy use is reduced by $13 \%$ by using an electric heating. The building envelope upgrades in Montreal for the all-electric building reduce the electricity consumption by $36 \%$, compared to the basic building heated by electricity, and by $56 \%$ for the building using both natural gas and electricity, like the base case in Vancouver. The electricity needs of the optimized electric only building in 
Montreal is consuming only $2 \%$ more energy than the building in Vancouver with the optimized building envelope, and the electricity bill is $11 \%$ less. The case of retrofit to the all-electric building in Vancouver was not evaluated, because buildings are usually demolished and rebuilt when deciding to change to an electric building [44], which is actually what happened to this case study building. The return on investment of the optimized building in Montreal was calculated using various debt ratio. The ROI of the building envelope was nearly 15 years and adding on-site renewable energy increases the ROI to 22.6 years (Table 12), for the building with both natural gas and electricity, as in the case of Vancouver. The increase in number of years is due to the lower cost of energy. If financing is needed, installing renewable energy on an office building Montreal with both natural gas and electricity is not profitable. However, other motivations can justify the installation, especially resilience toward extreme events having the potential to damage the electricity transport lines.

Table 12: Return on investment of the office upgrade scenario in Montreal

\begin{tabular}{|l|l|l|l|l|}
\hline Debt ratio & \multicolumn{3}{|c|}{ Return on investment } \\
\hline & \multicolumn{2}{|l|}{ Building envelope } & $\begin{array}{l}\text { Building envelope and renewable } \\
\text { energy }\end{array}$ \\
\hline $0 \%$ & 14.9 years & 22.6 years \\
\hline & Interest rate 2\% & Interest rate 7\% & $\begin{array}{l}\text { Interest rate } \\
2 \%\end{array}$ & Interest rate 7\% \\
\hline $10 \%$ & 15 years & 15.4 years & 22.8 years & 23.4 years \\
\hline $50 \%$ & 15.6 years & 17.5 years & 23.7 years & $\begin{array}{l}\text { More than 25 } \\
\text { years }\end{array}$ \\
\hline $90 \%$ & 16.2 years & 19.5 years & 24.5 years & $\begin{array}{l}\text { More than 25 } \\
\text { years }\end{array}$ \\
\hline
\end{tabular}

The use of a geothermal heat pump can also be a solution to reduce the consumption of the building. A classical geothermal heat pump in Quebec has an average between 3 and 5 in heating mode [45]. With this performance the efficiency in heating mode, and even in cooling mode, is gone improved. Furthermore, a direct expansion system [46] can also be used to reduce the installation part and decreased the return of investment. Installing water heat pumps in office building in China was also found to create $70 \%$ HVAC energy saving [13]. Moreover, additional building improvement is possible by using higher insulation for the walls, roof, windows, and floor; shades in the windows to limit heat gains in the summer and reduce air conditioning, water and energy-efficient appliances.

Thus, this case study shows that upgrading an existing office building in Vancouver can be profitable. However, this building was actually sold and demolish during the time this study was performed; while it is not the trend in most cities in North America and many building owners select energy efficiency measures to retrofit their building [2]. Buildings are demolished as a lower rate in Montreal. As the energy source for heating of most new 
buildings in Vancouver is mostly hydroelectric, the carbon payback is over 100 years, and with the very fast reconstruction rate, lower carbon goal will not be achieved, which suggest to reevaluate current policies to encourage new construction [44]. Material conservation is a guiding principle for low energy, low-carbon building and considered in the material credits of the LEED standard value [47]. The upgrade of existing office building must part of the building energy strategy and policy $[1,3,4]$.

\section{Conclusion}

This case study of a two-story office building in Vancouver shows that characteristics of the envelope are one of the most important parameters in the reduction of the building consumption, based on a sensitivity analysis and a parametric study. The improvement made on the building envelope in terms of airtightness and insulation allows to reduce of $45 \%$ of the annual energy consumed and saved 75 tons of $\mathrm{CO}_{2}$ gas equivalent. Net zero building performance is possible with the addition of solar collectors to heat the air and photovoltaic panels. It is important to highlight that the return on investment (ROI) of such a project is influenced by the building energy consumption, but also with the energy price in the studied city. The ROI to upgrade the building envelope is 7.7 years in Vancouver, while it is 14.9 years in Montreal. Installing on-site renewable energy is more profitable in Vancouver with a ROI of 11.6 years and a ROI of 22.6 years in Montreal.

To validate such a study, it is essential to realize measures of the real performances of the building with occupants. Only the follow-up of the performances allows making sure of the viability of a net zero and to obtain a certification which will allow to identify this

building as a net zero building. Furthermore, an analysis of sensibility could be interesting to estimate the robustness of the scenario of renovation in front of economic fluctuations, such as the energy price.

\section{Acknowledgment}

The authors thanks Mr. Graham Finch, Principal, Senior Building Science Specialist at $\mathrm{RDH}$ for his cooperation and his availability and in providing us all the necessary information to complete the study. Thanks are also accorded to Clément Rousseau and Charles Thibodeau for reviewing the manuscript.

\section{References}

[1] O. Pombo, B. Rivela, J. Neila, The challenge of sustainable building renovation: assessment of current criteria and future outlook, Journal of Cleaner Production, 123 (2016) 88-100.

[2] C.E. Kontokosta, Modeling the energy retrofit decision in commercial office buildings, Energy and Buildings, 131 (2016) 1-20.

[3] A. Passer, C. Ouellet-Plamondon, P. Kenneally, V. John, G. Habert, The impact of future scenarios on building refurbishment strategies towards plus energy buildings, Energy and Buildings, 124 (2016) 153-163. 
[4] J. Dettling, A. Pike, S. Humbert, Quantifying the Value of Building Reuse A Life Cycle Assessment of Rehabilitation and New Construction, in, Quantis US, Boston, USA, 2012, pp. 174.

[5] M. Fesanghary, S. Asadi, Z.W. Geem, Design of low-emission and energy-efficient residential buildings using a multi-objective optimization algorithm, Building and Environment, 49 (2012) 245-250.

[6] C. Micono, G. Zanzottera, Energy Modeling for NZEBs: A Case-study, Energy Procedia, 78 (2015) 2034-2039.

[7] C. Dotzler, S. Botzler, D. Kierdorf, W. Lang, Methods for optimising energy efficiency and renovation processes of complex public properties, Energy and Buildings, 164 (2018) 254-265.

[8] P.F.d.A.F. Tavares, A.M.d.O.G. Martins, Energy efficient building design using sensitivity analysis-A case study, Energy and Buildings, 39 (1) (2007) 23-31.

[9] T. Ramesh, R. Prakash, K.K. Shukla, Life cycle energy analysis of buildings: An overview, Energy and Buildings, 42 (10) (2010) 1592-1600.

[10] L.F. Cabeza, L. Rincón, V. Vilariño, G. Pérez, A. Castell, Life cycle assessment (LCA) and life cycle energy analysis (LCEA) of buildings and the building sector: A review, Renewable and Sustainable Energy Reviews, 29 (2014) 394-416.

[11] X. Oregi, P. Hernandez, R. Hernandez, Analysis of life-cycle boundaries for environmental and economic assessment of building energy refurbishment projects, Energy and Buildings, 136 (2017) 12-25.

[12] S.E. Chidiac, E.J.C. Catania, E. Morofsky, S. Foo, Effectiveness of single and multiple energy retrofit measures on the energy consumption of office buildings, Energy, 36 (8) (2011) 5037-5052.

[13] Z. Wang, Y. Ding, G. Geng, N. Zhu, Analysis of energy efficiency retrofit schemes for heating, ventilating and air-conditioning systems in existing office buildings based on the modified bin method, Energy Conversion and Management, 77 (2014) 233-242. [14] J. Jia, W.L. Lee, The rising energy efficiency of office buildings in Hong Kong, Energy and Buildings, 166 (2018) 296-304.

[15] S.H. Lee, T. Hong, M.A. Piette, G. Sawaya, Y. Chen, S.C. Taylor-Lange, Accelerating the energy retrofit of commercial buildings using a database of energy efficiency performance, Energy, 90 (2015) 738-747.

[16] E.M. El Khattabi, M. Mharzi, Effect of locations and thicknesses for the different material constituting a building wall, Energy Procedia, 139 (2017) 328-333.

[17] J. Lizana, R. Chacartegui, A. Barrios-Padura, J.M. Valverde, Advances in thermal energy storage materials and their applications towards zero energy buildings: A critical review, Applied Energy, 203 (2017) 219-239.

[18] G. Quesada, D. Rousse, Y. Dutil, M. Badache, S. Hallé, A comprehensive review of solar facades. Transparent and translucent solar facades, Renewable and Sustainable Energy Reviews, 16 (5) (2012) 2643-2651.

[19] G. Quesada, D. Rousse, Y. Dutil, M. Badache, S. Hallé, A comprehensive review of solar facades. Opaque solar facades, Renewable and Sustainable Energy Reviews, 16 (5) (2012) 2820-2832.

[20] A. Reilly, O. Kinnane, The impact of thermal mass on building energy consumption, Applied Energy, 198 (2017) 108-121. 
[21] S. Roberts, Altering existing buildings in the UK, Energy Policy, 36 (12) (2008) 4482-4486.

[22] P.K. Soori, S. Alzubaidi, Study on improving the energy efficiency of office building's lighting system design, in: 2011 IEEE GCC Conference and Exhibition (GCC), 2011, pp. 585-588.

[23] Y. Shao, P. Geyer, W. Lang, Integrating requirement analysis and multi-objective optimization for office building energy retrofit strategies, Energy and Buildings, 82 (2014) 356-368.

[24] S. Ferrari, M. Beccali, Energy-environmental and cost assessment of a set of strategies for retrofitting a public building toward nearly zero-energy building target, Sustainable Cities and Society, 32 (2017) 226-234.

[25] K. Carlson, D.K.D. Pressnail, Value impacts of energy efficiency retrofits on commercial office buildings in Toronto, Canada, Energy and Buildings, 162 (2018) 154162.

[26] G. Ruiz, C. Bandera, Validation of Calibrated Energy Models: Common Errors, Energies, 10 (10) (2017) 1587.

[27] O.R.N. Laboratory, U.S.D.o.E.O.o.E. Efficiency, R. Energy, U.S.D.o.E.O.o.

Scientific, T. Information, Empirical Validation of Building Energy Simulation Software: Energyplus, United States. Department of Energy. Office of Energy Efficiency and Renewable Energy, 2011.

[28] M. Trcka, J.M. Pasini, S.M. Oggianu, Validation of retrofit analysis simulation tool: Lessons learned

in: 3rd International High Performance Buildings Conference at Purdue, 2014. [29] D. Coakley, P. Raftery, M. Keane, A review of methods to match building energy simulation models to measured data, Renewable and Sustainable Energy Reviews, 37 (2014) 123-141.

[30] Y. Chae, Y. Lee, D. Longinott, Assessment of Retrofitting Measures for a Large Historic Research Facility Using a Building Energy Simulation Model, Energies, 9 (6) (2016) 466.

[31] A. Cacabelos, P. Eguía, L. Febrero, E. Granada, Development of a new multi-stage building energy model calibration methodology and validation in a public library, Energy and Buildings, 146 (2017) 182-199.

[32] S. Pander, Zero Emissions Building Plan, in: S.G. Green Building Manager (Ed.) Policy Report Development and Building, City of Vancouver, Vancouver, Canada, 2016, pp. 62.

[33] A. Pape-Salmon, BC Energy Step Code: A Best Practices Guide for Local

Governments, in, Government of British Columbia, British Columbia, Canada, 2017, pp. 52.

[34] C. Moning, Energy Study Report RDH Office Building, in: R.B.E. Ltd (Ed.), Vancouver, Canada, 2011, pp. 40.

[35] V.S.K.V. Harish, A. Kumar, A review on modeling and simulation of building energy systems, Renewable and Sustainable Energy Reviews, 56 (2016) 1272-1292.

[36] C. Smyth, G. Rampley, T. Lemprière, O. Schwab, W. Kurz, Estimating product and energy substitution benefits in national-scale mitigation analyses for Canada, 2016. [37] Hydro-Québec, Simulation énergétique des bâtiments, in, 2018. 
[38] RETScreen International, Clean Energy Project Analysis RETScreen Engineering \& Cases Textbook Third Edition Minister of Natural Resources Canada, Canada, 2005. [39] National Inventory Report 1990-2015: Greenhouse Gas Sources and Sinks in Canada, in: L.a.A.C.C.i. Publication (Ed.), Gatineau, CANADA, 2017. [40] C.n.d.r.d. Canada, Code national du bâtiment, Canada 2015, 2015. [41] Passive House Institute, Criteria for the Passive House, EnerPHit and PHI Low Energy Building Standard, in, Passive House Institute, Darmstadt, Germany 2016, pp. 27. [42] Z. Zhang, J.L. Provis, A. Reid, H. Wang, Geopolymer foam concrete: An emerging material for sustainable construction, Construction and Building Materials, 56 (0) (2014) $113-127$.

[43] N. Mousseau, Gagner la guerre du climat : douze mythes à déboulonner, Boréal, Montréal, 2017.

[44] J. Dahmen, J. von Bergmann, M. Das, Teardown Index: Impact of property values on carbon dioxide emissions of single family housing in Vancouver, Energy and Buildings, 170 (2018) 95-106.

[45] S.J. Self, B.V. Reddy, M.A. Rosen, Geothermal heat pump systems: Status review and comparison with other heating options, Applied Energy, 101 (2013) 341-348.

[46] C. Rousseau, J.-L.C. Fannou, L. Lamarche, S. Kajl, Modeling and Experimental Validation of a Transient Direct Expansion Heat Pump, International Journal of Renewable Energy Development; Vol 6, No 2 (2017): July 2017DO 10.14710/ijred.6.2.145-155, (2017).

[47] H.C. McCombs, LEED Green Associate Exam preparation guide LEED v4 edition, American technical publishers, Orland Park, Illinois, USA, 2015. 